\author{
Anna Bielawa* \\ Uniwersytet Szczeciński
}

\title{
POZIOM OCZEKIWAŃ I PERCEPCJI JAKOŚCI USŁUG SERWISOWO-NAPRAWCZYCH KOBIET I MĘŻCZYZN W AUTORYZOWANYCH SERWISACH SAMOCHODOWYCH
}

\begin{abstract}
Streszczenie
W artykule zaprezentowano zagadnienia dotyczące elementów badania jakości usług metodą Servqual, jakimi są oczekiwania i percepcja jakości usługi. Określono istotę ciągłego ich monitorowania oraz doskonalenia poziomu jakości usług serwisowo-naprawczych w autoryzowanych serwisach samochodowych. Przedstawiono wreszcie wyniki badań dotyczące oceny jakości usług serwisowo-naprawczych przeprowadzone w autoryzowanych serwisach osobno dla kobiet i mężczyzn, które następnie porównano w celu poznania ewentualnych podobieństw lub różnic.
\end{abstract}

Słowa kluczowe: jakość, usługi, autoryzowane serwisy samochodowe

\section{Wprowadzenie}

Wysoka jakość usług w obecnej rzeczywistości gospodarczej jest elementem, który powinien charakteryzować każde przedsiębiorstwo usługowe. Jest bardzo

\footnotetext{
* Adres e-mail: annabielawa@wp.pl.
} 
często warunkiem współpracy z innymi podmiotami gospodarczymi. Wyraźnie widać to w przypadku funkcjonowania autoryzowanych serwisów samochodowych. Każdy z nich, bez względu na to, w jakim państwie europejskim prowadzi działalność, musi spełniać identyczne wymagania jakościowe i działać w oparciu o procedury stawiane przez koncerny samochodowe danych marek.

Ponadto, jakość jest również rezultatem wewnętrznych działań przedsiębiorstwa. Proces zarządzania pozwala wykorzystać zasoby przedsiębiorstwa do zaspokojenia potrzeb zgłaszanych przez konsumentów usług. W przypadku przedsiębiorstw usługowych klienci mają istotny udział w kontroli realizacji procesu usługowego. Dlatego istotne jest zbieranie opinii klientów dotyczących ich oczekiwań oraz oceny przebiegu procesu realizacji, dzięki czemu możliwe staje się poznanie poziomu ich zadowolenia z jego wykonania. Pozwala to na zaplanowanie odpowiednich działań marketingowych czy też strategii działania wobec kluczowych klientów, ponieważ każda grupa klientów może mieć inne wymagania i potrzeby.

Jak wskazują zebrane podczas badania dane, poziom oczekiwań i postrzegania usługi mężczyzn różni się od wymagań stawianych przez kobiety oraz ich percepcji. W związku z tym celem niniejszego opracowania jest zaprezentowanie różnic i podobieństw w poziomie oczekiwań, percepcji jakości usług oraz ocenie jakości usług serwisowo-naprawczych pomiędzy kobietami a mężczyznami w autoryzowanych serwisach samochodowych po to, by móc określić obszary, na które kadra zarządzająca powinna zwrócić większą uwagę i starać się je udoskonalić.

\section{Oczekiwania a postrzeganie jakości usług}

Metoda Servqual wykorzystywana do badania jakości usług zakłada określenie przez respondentów poziomu oczekiwań, percepcji poszczególnych czynników jakości badanej usługi, jak również ważności kryteriów głównych. Następnie na podstawie zebranych danych dokonuje się pomiaru różnic pomiędzy ważonym poziomem postrzegania a poziomem oczekiwań w stosunku do badanych czynników ${ }^{1}$. Na tej podstawie określa się i ocenia poziom jakości usług. Sytuacją idealną jest stan, w którym oczekiwania klientów zostają spełnione, czyli równe są poziomowi percepcji. Oceniana różnica pomiędzy poziomem percepcji i oczekiwań wynosi w ta-

1 V.A. Zeithaml, A. Parasuraman, L.L. Berry, Delivering Quality Service, The Free Press, New York 1990, s. 19. 
kim przypadku 0 . Wynik ujemny świadczy o niedopasowaniu wykonywanej usługi do oczekiwań klientów, natomiast wynik dodatni o ich przekroczeniu.

Oczekiwania klientów to cechy usługi, których konsumenci pożądają i spodziewają się otrzymać 2 Są rozumiane również jako stan wewnętrzny, postawa lub nastawienie organizmu prowadzące do antycypacji danego zdarzenia lub inaczej: jako emocjonalny stan antycypacji ${ }^{3}$. Wymagania z kolei to zespół warunków, którym coś lub ktoś musi odpowiadać ${ }^{4}$. W kontekście klienta, jak się więc wydaje, wymagania dotyczą parametrów usług, a oczekiwania - sposobu, w jaki będzie ona świadczona. Wymagania są więc kategorią związaną z podejściem racjonalnym, natomiast oczekiwania - emocjonalnym 5 . Niemniej jednak A. Hamrol (za normą ISO 9000) traktuje te kategorie zamiennie i wskazuje, że „wymaganie, to potrzeba lub oczekiwanie, które zostało ustalone, jest przyjęte zwyczajowo lub jest obowiązkowe"'.

Oczekiwania powinny być ciągle i systematycznie monitorowane, ponieważ tylko dzięki temu przedsiębiorca jest w stanie dostosować ofertę, strategię marketingową do wymagań stawianych przez wszystkich lub grupę klientów ${ }^{7}$, np. przez kobiety lub mężczyzn. W proces dostosowywania się do pożądanej i oczekiwanej przez konsumentów jakości usług powinni być zaangażowani pracownicy różnych szczebli ${ }^{8}$.

Określony przez klienta poziom oczekiwań jest wynikiem posiadanego doświadczenia, indywidualnych preferencji, uprzedzeń, chwilowych i subiektywnych emocji, zasłyszanych opinii ${ }^{9}$. Oczekiwania klientów mogą wzrastać lub maleć. Indywidualne potrzeby jednostki powodują zazwyczaj wzrost oczekiwań, natomiast dotychczasowe doświadczenia konsumenta i skorzystanie z usług danej firmy w przeszłości niesie ze sobą spadek ich poziomu. Im większy prestiż firmy, więcej reklam i ogłoszeń, tym oczekiwania klienta są wyższe.

2 http://sjp.pwn.pl/szukaj/oczekiwanie.html (26.02.2015).

3 M. Stoma, Modele i metody pomiaru jakości ustug, Polihymnia, Lublin 2012, s. 28.

4 http://sjp.pwn.pl/szukaj/wymagania.html (26.02.2015).

5 M. Stoma, op.cit., s. 28.

6 A. Hamrol, Zarządzanie jakościa z przykładami, Wydawnictwo Naukowe PWN, Warszawa 2008, s. 470.

7 M. Urbaniak, Zarządzanie jakością. Teoria i praktyka, Difin, Warszawa 2004, s. 25.

8 A. Tokarz, Ekonomika ustug. Przewodnik, Wydawnictwo Naukowe Uniwersytetu Szczecińskiego, Szczecin 2005, s. 106.

9 Z. Zymonik, A. Hamrol, P. Grudowski, Zarzadzanie jakościa i bezpieczeństwem, PWE, Warszawa 2013, s. 46. 
Oprócz zbadania poziomu oczekiwań w metodzie Servqual zbiera się również opinie dotyczące poziomu wykonania danej usługi. Służyć ma to, jak było wspomniane wcześniej, do określenia poziomu zadowolenia klienta z usługi. Ponadto, badanie percepcji wykorzystuje się również do ${ }^{10}$ :

- poznania wymagań istotnych w procesie doskonalenia,

- uzyskania danych do monitorowania usprawnień,

- wzrostu wskaźników utrzymania klientów,

- tworzenia wartości dla klienta,

- spełnienia wymogów normy ISO 9001.

\section{Poziom oczekiwań i percepcji jakości usług w autoryzowanych ser- wisach samochodowych}

Poziom oczekiwań i postrzegania jakości usług serwisowo-naprawczych został określony z wykorzystaniem kwestionariusza ankiety, która opierała się na metodzie Servqual. Wyróżnione w badaniu czynniki jakości usług zostały dobrane w taki sposób, aby jak najlepiej odzwierciedlić poziom jakości usług serwisowo-naprawczych. Pogrupowano je w sześć głównych kryteriów jakości usług - materialności, niezawodności, zdolności reagowania, kompetentności pracowników, przystępności usługi oraz bezpieczeństwa.

Badania przeprowadzono wśród klientów autoryzowanych serwisów samochodowych 6 najbardziej popularnych marek samochodów w Polsce - Škody, Forda, Volkswagena, Toyoty, Fiata i Opla na terenie województwa zachodniopomorskiego. Zwrócono 312 kompletnie wypełnionych ankiet (z rozdystrybuowanych 900).

W trakcie analizy danych zauważono, że oczekiwania i percepcja jakości usług kobiet różni się od poziomu wskazywanego przez mężczyzn. Jak wskazuje tabela 1, kobiety mają niższe niż mężczyźni oczekiwania wobec jakości usług serwisowo-naprawczych. Jedynie w przypadku terminowości odnotowano nieznacznie wyższe wymagania. Największe różnice w poziomie oczekiwań pomiędzy kobietami i mężczyznami wystąpiły w odniesieniu do czynników jakości usług: niezawodności i uczciwości przy rozliczeniach. Najmniejsze z kolei w stosunku do czystości wnętrza.

10 A. Hamrol, op.cit., s. 470. 
Tabela 1. Poziom oczekiwań wobec jakości usług serwisowo-naprawczych według płci

\begin{tabular}{|c|c|c|c|c|c|}
\hline \multicolumn{2}{|c|}{ Kryteria jakości } & $\begin{array}{l}\text { Wyróżniki (determinanty) } \\
\text { jakości usług }\end{array}$ & $\begin{array}{l}\text { Oczekiwania } \\
\text { kobiet }\end{array}$ & $\begin{array}{l}\text { Oczekiwania } \\
\text { mężczyzn }\end{array}$ & $\begin{array}{c}\text { Różnica } \\
\text { oczekiwań pomię- } \\
\text { dzy mężczyznami } \\
\text { a kobietami }\end{array}$ \\
\hline \multirow{3}{*}{ 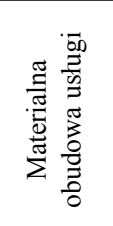 } & 1. & Czystość wnętrza & 4,25 & 4,31 & 0,06 \\
\hline & 2. & Ujednolicony wystrój wnętrza & 3,63 & 3,83 & 0,20 \\
\hline & 3. & Materiały informacyjne i promocyjne & 4,29 & 4,47 & 0,18 \\
\hline \multirow{3}{*}{ 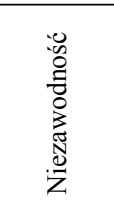 } & 4. & Terminowość & 4,63 & 4,61 & $-0,02$ \\
\hline & 5. & Staranność realizacji usługi & 4,42 & 4,68 & 0,26 \\
\hline & 6. & $\begin{array}{l}\text { Poprawność wykonania usługi } \\
\text { za pierwszym razem }\end{array}$ & 4,29 & 4,91 & 0,62 \\
\hline \multirow{5}{*}{ 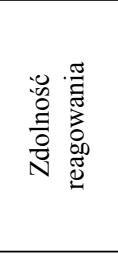 } & 7. & Prawdomówność pracowników & 4,38 & 4,6 & 0,22 \\
\hline & & & & & \\
\hline & 8. & Szybkość reakcji & 3,96 & 4,46 & 0,50 \\
\hline & 9. & Doradztwo i konsultacje & 3,96 & 4,66 & 0,70 \\
\hline & 10. & $\begin{array}{l}\text { Zaangażowanie w proces realizacji } \\
\text { usługi }\end{array}$ & 3,96 & 4,34 & 0,38 \\
\hline \multirow{4}{*}{ 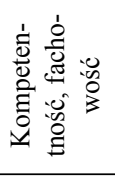 } & 11. & Sposób zachowania pracowników & 4,00 & 4,54 & 0,54 \\
\hline & 12. & Uczciwość przy rozliczeniach & 4,00 & 4,64 & 0,64 \\
\hline & 13. & Życzliwość pracowników & 3,96 & 4,34 & 0,38 \\
\hline & 14. & Kompetentność pracowników & 4,13 & 4,61 & 0,48 \\
\hline \multirow{3}{*}{ 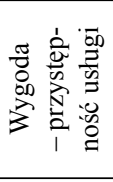 } & 15. & Indywidualność oferty & 4,13 & 4,29 & 0,16 \\
\hline & 16. & Dostęp do oferty firmy & 4,17 & 4,25 & 0,08 \\
\hline & 17. & Łatwość kontaktu z pracownikami & 4,00 & 4,08 & 0,08 \\
\hline \multirow{4}{*}{$\begin{array}{l}0 \\
0 \\
0 \\
D \\
N \\
0 \\
.00 \\
D \\
D \\
D\end{array}$} & 18. & Technologia & 4,38 & 4,64 & 0,26 \\
\hline & 19. & Legalizacja urządzeń & 4,17 & 4,29 & 0,12 \\
\hline & 20. & $\begin{array}{l}\text { Najwyższej jakości części zamienne } \\
\text { i materiały eksploatacyjne }\end{array}$ & 4,29 & 4,53 & 0,24 \\
\hline & 21. & $\begin{array}{l}\text { Odpowiedzialność za stan środowiska } \\
\text { naturalnego }\end{array}$ & 3,88 & 4,06 & 0,18 \\
\hline
\end{tabular}

Źródło: opracowanie własne na podstawie przeprowadzonych badań. 
Dla kobiet najważniejsza jest terminowość usługi i staranność jej wykonania. Najmniejszą wagę przykładają z kolei do ujednoliconego wystroju wnętrza i odpowiedzialności za stan środowiska naturalnego (właściwej utylizacji odpadów przez pracowników).

Mężczyźni największe oczekiwania mają wobec poprawności wykonania usługi już za pierwszym razem, najmniejsze (podobnie jak kobiety) - ujednoliconego wystroju wnętrza.

Zarówno mężczyźni, jak i kobiety wymagają wysokiego poziomu jakości usług serwisowo-naprawczych. W pięciostopniowej skali Likerta średni poziom oczekiwań kobiet wynosił 4,14, a mężczyzn 4,46.

Jak wskazuje tabela 2, wszyscy respondenci bez względu na płeć są krytyczni w ocenach poziomu jakości świadczonych usług serwisowo-naprawczych, z których skorzystali. Przeciętna percepcja ocenianych czynników jakości w żadnym przypadku nie przekroczyła 4 (klienci oceniali czynniki w pięciostopniowej skali Likerta).

Jak wskazują wyniki badań, respondentki najlepiej postrzegają kulturę osobistą pracowników, ich życzliwość i uprzejmość, najgorzej natomiast czytelność broszur informacyjnych i dokumentacji serwisowo-naprawczej. Mężczyźni natomiast najgorzej postrzegają terminowość usług oraz uczciwość przy rozliczeniach. Docenili z kolei dostępność do oferty firmy, wystrój wnętrza, stosowaną technologię oraz jakość części zamiennych i materiałów eksploatacyjnych.

Porównując poziom percepcji kobiet i mężczyzn widoczne stają się znaczne różnice w dokonywanych ocenach. Największe rozbieżności dotyczą prawdomówności pracowników (gorzej oceniona przez mężczyzn), życzliwości pracowników (kobiety lepiej oceniły ich poziom uprzejmości), terminowości (przez mężczyzn dotrzymanie ustalonego terminu wykonania usługi było gorzej postrzegane).

Kobiety i mężczyźni na zbliżonym poziomie postrzegali łatwość kontaktu z pracownikiem, dostęp do oferty firmy oraz czytelność materiałów informacyjnych i promocyjnych. 
Tabela 2. Poziom percepcji wobec jakości usług serwisowo-naprawczych według płci

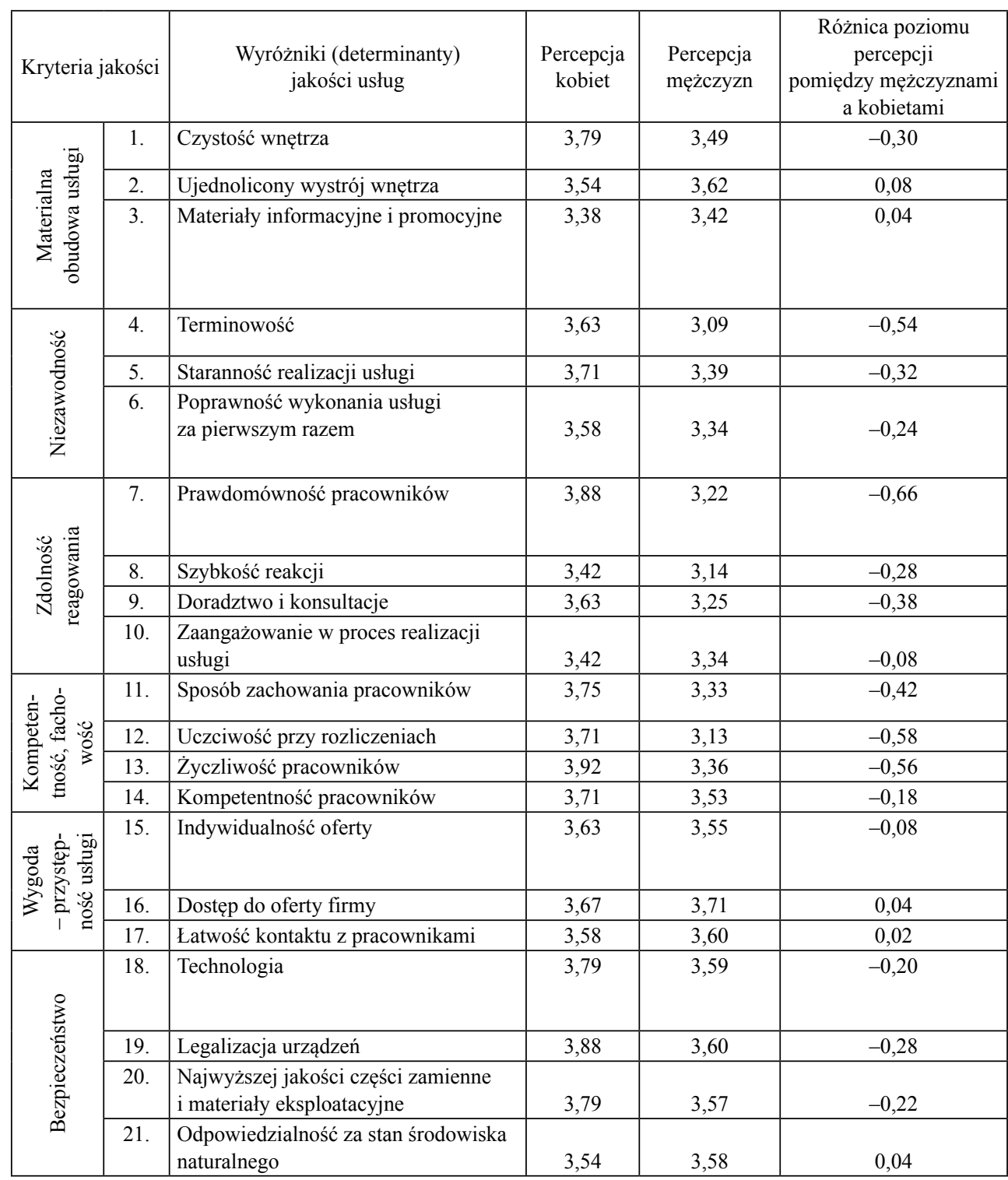

Źródło: opracowanie własne na podstawie przeprowadzonych badań. 
Tabela 3. Ocena jakości według wyodrębnionych czynników jakości usług z punktu widzenia kobiet i mężczyzn

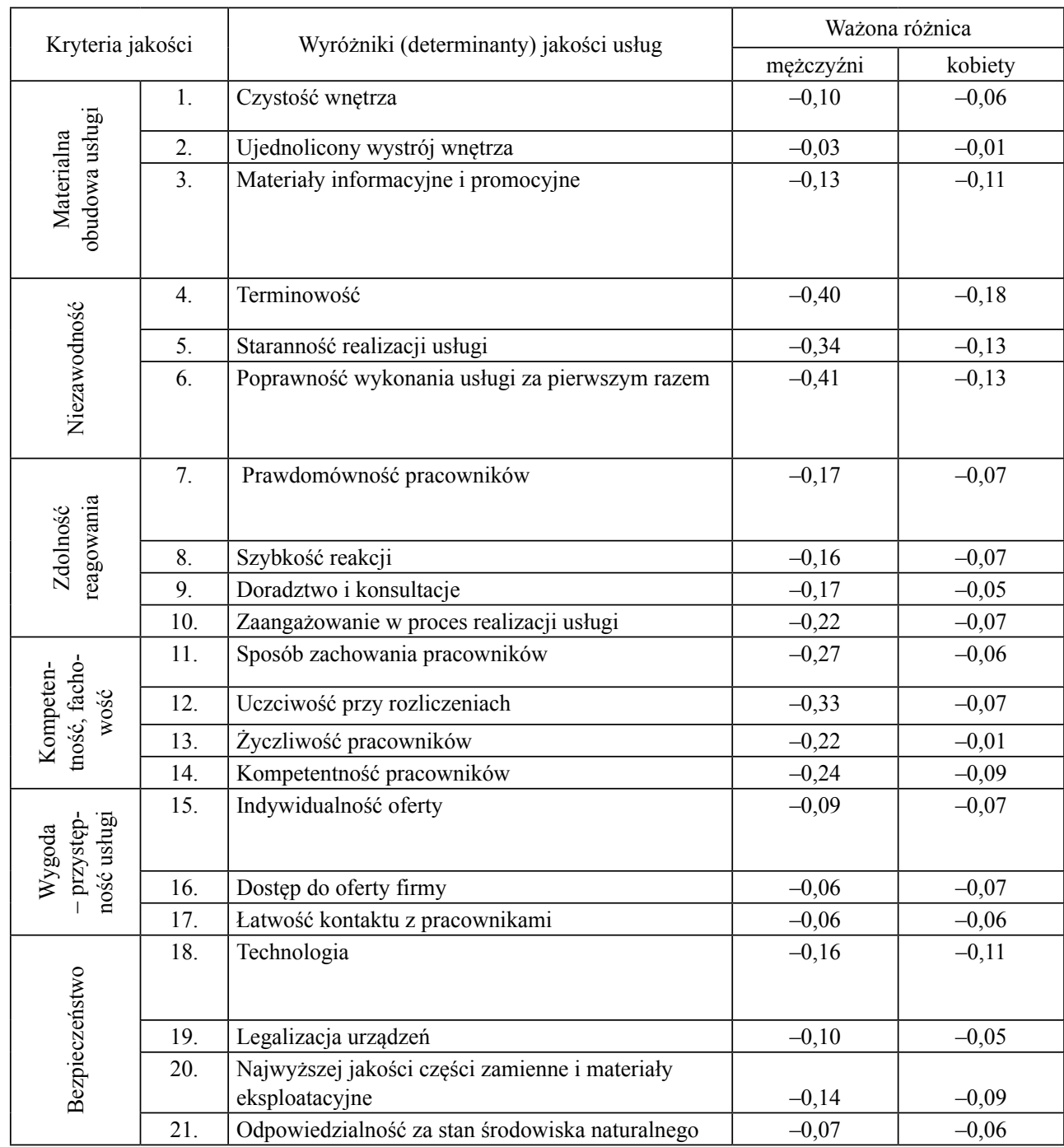

Źródło: opracowanie własne na podstawie przeprowadzonych badań. 
Tabela 3 prezentuje ocenę jakości wyodrębnionych czynników jakości dokonaną przez klientów zewnętrznych autoryzowanych serwisów samochodowych. W przypadku mężczyzn najmniejszy dysonans między oczekiwaniami i percepcją występuje w przypadku wystroju wnętrza oraz czynników związanych z przystępnością usługi - odpowiednią lokalizacją, godzinami otwarcia, przystępnością pracowników. Największy z kolei w przypadku czynników związanych z niezawodnością, czyli: poprawnym wykonaniem usług już za pierwszym razem oraz dotrzymaniem przyrzeczonego terminu wykonania usługi. Wśród kobiet nieznaczną różnicę, a więc prawie idealne dopasowanie do oczekiwań, zaobserwowano w przypadku wystroju wnętrza oraz życzliwości i uprzejmości pracowników, najmniejsze z kolei dotyczy wszystkich czynników związanych z kryterium niezawodności.

Porównując ważone różnice pomiędzy poziomem percepcji i oczekiwań jakości usług, można stwierdzić, że kobiety lepiej oceniają poszczególne czynniki jakości usług serwisowo-naprawczych aniżeli mężczyźni. Znajduje to również swoje odzwierciedlenie w ocenie jakości poszczególnych wymiarów oraz całkowitym wskaźniku Servqual.

Tabela 4. Ważona i nieważona wartość Servqual dla kobiet

\begin{tabular}{|c|c|c|c|c|}
\hline \multicolumn{5}{|c|}{ SQnw i SQww dla poszczególnych wymiarów } \\
\hline Wymiar & \multicolumn{2}{|l|}{ SQnw } & \multicolumn{2}{|l|}{ SQww } \\
\hline Wymiar 1 - materialność & \multicolumn{2}{|l|}{$\mathrm{SQn} 1=-0,49$} & \multicolumn{2}{|l|}{$\mathrm{SQw} 1=-0,06$} \\
\hline Wymiar 2 - niezawodność & \multicolumn{2}{|l|}{$\mathrm{SQn} 2=-0,81$} & \multicolumn{2}{|l|}{ SQw2 $=-0,15$} \\
\hline Wymiar 3 -zdolność reagowania & \multicolumn{2}{|l|}{$\mathrm{SQn} 3=-0,48$} & \multicolumn{2}{|l|}{ SQw3 $=-0,07$} \\
\hline Wymiar 4 - kompetentność & \multicolumn{2}{|l|}{$\mathrm{SQn} 4=-0,25$} & \multicolumn{2}{|l|}{ SQw4 $=-0,06$} \\
\hline Wymiar 5 - wygoda & \multicolumn{2}{|l|}{$\mathrm{SQn} 5=-0,47$} & \multicolumn{2}{|l|}{ SQw5 $=-0,07$} \\
\hline \multirow{2}{*}{ Wymiar 6 - bezpieczeństwo } & \multicolumn{2}{|l|}{$\mathrm{SQn} 6=-0,43$} & \multicolumn{2}{|l|}{ SQw6 $=-0,08$} \\
\hline & $\begin{array}{l}\text { Średnia miara arytme- } \\
\text { tyczna całkowita }\end{array}$ & $\begin{array}{l}\mathrm{SQn}= \\
-0,49\end{array}$ & $\begin{array}{c}\text { Średnia miara } \\
\text { ważona całkowita }\end{array}$ & $\begin{array}{c}\mathrm{SQw}= \\
-0,47\end{array}$ \\
\hline \multicolumn{5}{|c|}{$\begin{array}{l}\text { SQnw - wskaźnik Servqual nieważony dla j-ego wymiaru } \\
\text { SQww - wskaźnik Servqual ważony dla j-ego wymiaru }\end{array}$} \\
\hline
\end{tabular}


Tabela 5. Ważona i nieważona wartość Servqual dla mężczyzn

\begin{tabular}{|c|c|c|c|c|}
\hline \multicolumn{5}{|c|}{ SQnw i SQww dla poszczególnych wymiarów } \\
\hline Wymiar & \multicolumn{2}{|l|}{ SQnw } & \multicolumn{2}{|l|}{ SQww } \\
\hline Wymiar 1 - materialność & \multicolumn{2}{|l|}{ SQn1 $=-0,69$} & \multicolumn{2}{|l|}{$\mathrm{SQw} 1=-0,08$} \\
\hline Wymiar 2 - niezawodność & \multicolumn{2}{|l|}{$\mathrm{SQn} 2=-1,46$} & \multicolumn{2}{|l|}{$\mathrm{SQw} 2=-0,38$} \\
\hline Wymiar 3 - zdolność reagowania & \multicolumn{2}{|l|}{$\mathrm{SQn} 3=-1,28$} & \multicolumn{2}{|l|}{$\mathrm{SQw} 3=-0,18$} \\
\hline Wymiar 4 - kompetentność & \multicolumn{2}{|l|}{$\mathrm{SQn} 4=-1,20$} & \multicolumn{2}{|l|}{$\mathrm{SQw} 4=-0,26$} \\
\hline Wymiar 5 - wygoda & \multicolumn{2}{|l|}{$\mathrm{SQn} 5=-0,59$} & \multicolumn{2}{|l|}{ SQw5 $=-0,07$} \\
\hline \multirow[t]{2}{*}{ Wymiar 6 - bezpieczeństwo } & \multicolumn{2}{|l|}{$\mathrm{SQn} 6=-0,80$} & \multicolumn{2}{|l|}{ SQw6 $=-0,12$} \\
\hline & $\begin{array}{l}\text { Średnia miara aryt- } \\
\text { metyczna całkowita }\end{array}$ & $\begin{array}{l}\mathrm{SQn}= \\
-1,00\end{array}$ & $\begin{array}{c}\text { Średnia miara ważona } \\
\text { całkowita }\end{array}$ & $\begin{array}{l}\mathrm{SQw}= \\
-1,09\end{array}$ \\
\hline
\end{tabular}

Źródło: opracowanie własne na podstawie przeprowadzonych badań.

Analizując tabele 4 i 5, dostrzega się fakt, iż ankietowane kobiety lepiej oceniły oferowaną im jakość usług serwisowo-naprawczych (całkowita wartość Servqual równa jest $-0,47$ ), chociaż $\mathrm{w}$ żadnym przypadku ich oczekiwania nie zostały spełnione w $100 \%$. Respondentki doceniły wystrój wnętrza oraz kompetentność pracowników. Jednocześnie bardzo słabo oceniły elementy związane z niezawodnością usługi - terminowość, staranność wykonania i poziom zaangażowania pracowników. Są to czynniki, które zależą bezpośrednio od personelu wykonującego usługę i mogą świadczyć albo o małej wiedzy i umiejętnościach, albo o słabej motywacji do pracy.

Obie miary Servqual (ważona i nieważona) przyjmują wartości ujemne (zarówno wśród kobiet, jak i mężczyzn), które są konsekwencją przyjętych do dalszej analizy ujemnych wartości ocen klientów zewnętrznych ${ }^{11}$. Jeśli chodzi o wartości ważone, wśród mężczyzn najlepiej został oceniony wymiar 5 - wygoda oraz podobnie jak u kobiet materialna obudowa usługi (wymiar 1). Największa luka jakości uwidoczniła się w kryterium niezawodności usługi.

11 Różnica między percepcją a oczekiwaniami w stosunku do usługi. 
Jednocześnie wartości całkowite Servqual (nieważone i ważone) przyjmują wartości stosunkowo wysokie, co świadczy mimo wszystko o dość wysokiej jakości usług serwisowo-naprawczych widzianej oczyma klienta zewnętrznego. Niemniej jednak należy zauważyć, że kobiety znacznie wyżej (bo aż o 130\%) oceniły jakość świadczonych usług serwisowo-naprawczych aniżeli mężczyźni.

\section{Podsumowanie}

Wejście Polski do Unii Europejskiej spowodowało bardzo istotne zmiany w zakresie przepisów dotyczących tworzenia i funkcjonowania autoryzowanych serwisów samochodowych. Zmiany pozwoliły na rozwój serwisów niezależnych, czym pobudziły konkurencyjność w tym sektorze. Dlatego, aby pozyskać nowych i utrzymać obecnych klientów, autoryzowane serwisy samochodowe powinny stale monitorować jakość swoich usług, która jest wypadkową oczekiwań, jakie stawia przed nią konsument, oraz poziomu jej postrzegania. Pozwala to na doskonalenie oferowanych usług i co za tym idzie - lepsze dopasowanie się do wymagań usługobiorców. Jak wskazały badania, kobiety lepiej oceniają jakość oferowanych usług serwisowo-naprawczych aniżeli mężczyźni. Obie grupy respondentów mają największe oczekiwania wobec wymiaru niezawodności usługi, ale różnych jego czynników. Dla kobiet istotne jest dotrzymanie przyrzeczonego terminu wykonania usługi, dla mężczyzn z kolei poprawność jej wykonania już za pierwszym razem. Jednocześnie ten wymiar postrzegany jest najgorzej, co przekłada się na jego końcową ocenę jakościową. Informacja ta powinna być zatem przesłanką dla osób zarządzających autoryzowanymi serwisami samochodowymi do zintensyfikowania działań mających na celu poprawę tego obszaru.

Badania metodą Servqual powinny być wykonywane systematycznie, by móc monitorować efekty działań, które podejmuje przedsiębiorstwo w celu doskonalenia jakości swoich usług, dlatego jako kierunek dalszych badań należałoby wskazać powtórzenie badania na wybranej wcześniej grupie respondentów, aby potwierdzić zasadność albo jej brak podjętych działań udoskonalających. 


\title{
Literatura
}

Hamrol A., Zarządzanie jakościq z przykładami, Wydawnictwo Naukowe PWN, Warszawa 2008.

http://sjp.pwn.pl/szukaj/oczekiwanie.html (26.02.2015).

http://sjp.pwn.pl/szukaj/wymagania.html (26.02.2015).

Stoma M., Modele i metody pomiaru jakości ustug, Polihymnia, Lublin 2012.

Tokarz A., Ekonomika ushug. Przewodnik, Wydawnictwo Naukowe Uniwersytetu Szczecińskiego, Szczecin 2005.

Urbaniak M., Zarzadzanie jakością. Teoria i praktyka, Difin, Warszawa 2004.

Zeithaml V.A., Parasuraman A., Berry L.L., Delivering Quality Service, The Free Press, New York 1990.

Zymonik Z., Hamrol A., Grudowski P., Zarządzanie jakościq i bezpieczeństwem, PWE, Warszawa 2013.

\section{THE LEVEL OF WOMEN'S AND MEN'S EXPECTATIONS AND PERCEPTION OF THE QUALITYOF REPAIR SERVICES IN AUTHORIZED CAR SERVICES}

\begin{abstract}
The article is based on the results of the research, which was conducted in authorized car services. It describes the elements of Servqual method, what are the expectations and perceptions of service quality. Defined the essence of excellence and continuous monitoring the level of service quality in authorized car services. Finally presents the results of the research - the level of expectations and perceptions and service quality, separately for men and women.
\end{abstract}

Translated by Anna Bielawa

Keywords: quality, services, authorized car services

JEL Code: L84 